\title{
INFLUENCE OF ANGULAR EXPOSURE AND PROXIMITY TO VEHICULAR TRAFFIC ON THE DIVERSITY OF EPIPHYTIC LICHENS AND THE BIOACCUMULATION OF TRAFFIC-RELATED ELEMENTS
}

\author{
Luca Paoli ${ }^{1,2}$, Silvana Munzi ${ }^{1,3}$, Elisa Fiorini ${ }^{1}$, Carlo Gaggi ${ }^{1}$, Stefano Loppi ${ }^{1, *}$ \\ ${ }^{1}$ Department of Environmental Science, University of Siena, Italy \\ ${ }^{2}$ Institute of Botany, Slovak Academy of Sciences \\ ${ }^{3}$ Centre for Environmental Biology, University of Lisbon, Portugal
}

\begin{abstract}
Purpose This study investigated the influence of angular exposure and distance from vehicular traffic on the diversity of epiphytic lichens and the bioaccumulation of traffic-related elements in a town of central Italy.

Methods An Index of Lichen Diversity (ILD) was calculated on the street-facing and the opposite side of road lining trees and in a urban park $250 \mathrm{~m}$ away, and the content of selected trace elements (Al, $\mathrm{Ba}, \mathrm{Ce}, \mathrm{Cd}, \mathrm{Cr}, \mathrm{Cu}, \mathrm{Fe}, \mathrm{Mn}, \mathrm{Ni}$, $\mathrm{Pb}, \mathrm{Sb}, \mathrm{V}, \mathrm{Zn}$ ) was determined in samples of the lichen Punctelia borreri (Sm.) Krog growing on tree bark, both on the exposed and opposite sides.

Results ILD increases with distance from traffic emissions. However, at the site with vehicle traffic, non-nitrophilous lichens decreased while nitrophilous ones increased. The concentration of the traffic-related elements $\mathrm{Ba}, \mathrm{Cr}, \mathrm{Cu}, \mathrm{Mn}$, $\mathrm{Sb}$ and $\mathrm{Zn}$ accumulated in thalli of $P$. borreri was higher on roadside trees than in trees from the urban park. ILD was not affected by the angular exposure to the road and the bioaccumulation of traffic-related elements was similar in lichens from the side of the bole exposed to traffic emissions and particulate resuspension and from the opposite side. Conclusion The angular exposure respect to the traffic source does not influence trace element accumulation. These results are important when using lichens for biomonitoring purposes, both for planning future studies and for the reliability of the interpretation of past surveys that do not report information about the angular exposure of the collected lichen material.
\end{abstract}

Key words: Air pollution, Bioaccumulation, Biomonitoring, Heavy metals, Lichen diversity, Traffic-related elements

\section{Introduction}

Vehicular traffic is the main source of particulate matter and airborne metals in urban environments (Cadle et al. 1997) and a major source of $\mathrm{CO}, \mathrm{VOCs}, \mathrm{SO}_{2}$ and $\mathrm{NO}_{\mathrm{x}}$ produced by fuel combustion (Campo et al. 1996) and $\mathrm{NH}_{3}$ formed inside catalytic converters (Sutton et al., 2000). Emission of traffic-related elements (TRE) originates from fuel combustion $(\mathrm{Pb}$ and $\mathrm{Ba})$, tire, brake, engine and vehicle components deterioration $(\mathrm{Cd}, \mathrm{Cr}, \mathrm{Cu}, \mathrm{Fe}, \mathrm{Mn}, \mathrm{Ni}, \mathrm{Sb}, \mathrm{V}$ and $\mathrm{Zn}$ ) and, indirectly, by resuspension of soil (Al, Fe and associated elements) and street dust (Bargagli 1998; Garty 2001).

Catalytic converters minimize toxic emissions produced during gas combustion by means of some platinum group elements (PGE) i.e. Pt, Pd and Rh, and Cerium (Ce), but upon their corrosion and deterioration, these elements are released as well into the environment (Helmers 1996; Helmers 2000; Morcelli et al. 2005). Antimony (Sb), owing to its stabilising properties, is often used in a number of alloys for motor bearings and it is found associated with the release of TRE into the environment following brake pads deterioration (Von Uexküll et al. 2005). Barium is used in unleaded 
gasoline and diesel oil and has many applications in the automotive industry, including rubber production, lubricating oil additives and fuel synthesis. Consequently, Ba was found in urban street dust (Hopke et al. 1980) and in diesel- and unleaded gasoline-powered vehicle emissions (Lowenthal et al. 1994; Que Hee 1994). Barium and antimony have been recognized as suitable new tracers for vehicle emissions in place of lead, traditionally linked in the past to motor combustion processes (Monaci et al. 2000; Fujiwara et al. 2011).

Lichens are among the most valuable biomonitors of atmospheric pollution (Ferry et al. 1973). The diversity of epiphytic lichens is used as a sensitive indicator of the biological effects of air pollutants by means of standard procedures (e.g. Asta et al. 2002) and the mapping of lichen diversity is becoming routine in several countries (Nimis et al. 2002) since it is quick and inexpensive and provides results on which predictions for human health can be based (Cislaghi and Nimis 1997). In addition to floristic changes, lichens have been widely used for monitoring deposition patterns of heavy metals (Garty 1993; Bačkor and Loppi 2009). In fact, lichens are known for their ability to accumulate airborne substance to concentrations far greater than those in the atmosphere, and the element contents of lichen thalli proved to be directly correlated with environmental levels (Sloof 1995; Bari et al. 2001).

Investigations carried out to estimate air quality in proximity of roads, road intersections and highways, showed decreasing concentrations of gaseous pollutants (especially $\mathrm{NO}_{\mathrm{x}}$ ) and heavy metals (especially $\mathrm{Pb}$ ) within few tenths of meters from traffic roads (Garty 2001; Cape et al. 2004).

Although a large amount of data is available on the distance-dependent distribution of traffic-related pollutants, only few studies investigated the angular distribution of epiphytic lichens (Del Guasta 2000) and TRE (Bargagli 1998) in relation to the source of pollution.

In this work we investigated whether an asymmetrical distribution of epiphytic lichens and element concentrations accumulated in lichen thalli exists in relation to angular exposure and proximity to vehicle traffic in a town of central Italy. To this purpose, an Index of Lichen Diversity (ILD) was calculated on the street-facing and the opposite side of road lining trees and in a urban park $250 \mathrm{~m}$ away, and the content of selected trace elements was determined in samples of the lichen Punctelia borreri growing on tree bark, both on the exposed and the opposite sides.

\section{Materials and Methods}

\subsection{Study sites}

The study was performed at two selected sites in the urban area of Siena, a small town (ca. 60,000 inhab.) in Tuscany, central Italy. The elevation of the town is ca. $300 \mathrm{~m}$ asl. Climate is sub-Mediterranean, with a mean annual temperature of $13.9^{\circ} \mathrm{C}$ and a mean annual rainfall of ca. $800 \mathrm{~mm}$, which is concentrated in autumn and winter, while summer is fairly dry. Economy is mainly based on tourism and industrial activity is limited, and hence vehicular traffic and domestic heating are the main sources of atmospheric pollution. Air pollution in the town is moderate, as confirmed by recent instrumental monitoring (ARPAT 2010). Measured pollutants are all within legal limits (yearly average [legal limits]): $\mathrm{NO}_{2}\left(29 \mu \mathrm{g} / \mathrm{m}^{3}\right.$ [40]), $\mathrm{PM}_{10}\left(28 \mu \mathrm{g} / \mathrm{m}^{3}\right.$ [40]), benzene $\left(0.9 \mu \mathrm{g} / \mathrm{m}^{3}[5]\right)$ and $\mathrm{CO}\left(0.4 \mathrm{mg} / \mathrm{m}^{3}[10]\right)$.

The first study site is a busy one-way road close to the town centre with a flow of ca. 800 slow-moving cars per hour during the day. The second site is the urban park in the ancient city fortress, ca. $250 \mathrm{~m}$ as the crow flies from the first site.

\subsection{Sampling design}


Ten lime trees (Tilia platyphyllos Scop.), which are frequent along avenues and in public parks of Siena, and are commonly used as phorophyte in lichen biomonitoring studies, were randomly selected at the two study sites. For each tree, the street-facing side (centered at $40^{\circ}, \mathrm{NE}$ ), and the opposite side (centered at $220^{\circ}, \mathrm{SW}$ ) were sampled. Tree boles were deemed suitable if well lit, with girth $>70 \mathrm{~cm}$, trunk almost straight, not damaged and with bryophytes covering less than $25 \%$.

\subsection{Lichen diversity}

The diversity of epiphytic lichens was measured using a $20 \times 50 \mathrm{~cm}$ sampling grid, divided into 10 units of $10 \times 10 \mathrm{~cm}$ each. The grid was placed $1 \mathrm{~m}$ above ground, respectively on the road- and the opposite side. For each tree, an Index of Lichen Diversity (ILD) was calculated as the sum of frequencies of epiphytic lichens, namely the number of grid units in which the species occurred. Nomenclature follows the on-line database ITALIC (Nimis and Martellos 2008).

\subsection{Bioaccumulation of trace elements}

Punctelia borreri (Sm.) Krog is a broad-lobed mesophilous lichen that grows in weakly eutrophicated environments, especially on subneutral barked-trees (Van Herk and Aptroot 2000; Nimis and Martellos 2008). The species is quite common on Tilia in Siena and it has been selected for elemental analysis being available in both the study sites. It was reported from previous lichen monitoring in the town included within Parmelia subrudecta group (Loppi et al. 2002). At each site, up to 30 thalli growing on the bole of Tilia were harvested on road lining trees and in the urban park, 15 from the street side and 15 from the opposite side, along a belt $\left(45^{\circ}\right.$ width) between 100 and $200 \mathrm{~cm}$ from ground. In the laboratory, samples were carefully cleaned under a binocular microscope to remove extraneous material deposited onto the surface, such as moss samples, bark pieces and soil particles.

Only the peripheral parts of the thalli (up to $5 \mathrm{~mm}$ from lobe tips) were selected for the analysis; in P. borreri this part roughly corresponds to the biomass produced during the last year and can be easily separated from the bark. The content of trace elements was measured according to standard procedures (Bettinelli et al. 1996). Unwashed samples were air-dried to constant weight, pulverized and homogenized with a ceramic mortar and pestle and liquid nitrogen. About $200 \mathrm{mg}$ of powdered lichen material was mineralized with a mixture of $6 \mathrm{~mL}$ of $70 \% \mathrm{HNO}_{3}, 0.2 \mathrm{~mL}$ of $60 \% \mathrm{HF}$ and $1 \mathrm{~mL}$ of $30 \% \mathrm{H}_{2} \mathrm{O}_{2}$ in a microwave digestion system (Milestone Ethos 900 ) at $280^{\circ} \mathrm{C}$ and 55 bars.

Concentrations of 13 selected elements (Al, Ba, Ce, Cd, Cr, Cu, Fe, Mn, Ni, Pb, Sb, V and Zn) were determined by ICPMS (Perkin Elmer - Sciex, Elan 6100) and expressed on a dry weight basis ( $\mu \mathrm{g} / \mathrm{g} \mathrm{dw})$.

Analytical quality was checked by analyzing the Standard Reference Material IAEA-336 'lichen'. Precision of analysis was found to be within $8 \%$ for all elements. For each experimental condition, three independent aliquots were prepared for analysis and three replicates of measurements were run.

\subsection{Statistical analysis}

For ILD values, species frequencies and element concentrations, a two-way analysis of variance (ANOVA) was run to investigate the effects of site (roadside trees and urban park) and angular exposure to traffic (street-facing and sheltered side of the bole) and their possible interactions. Results of ANOVA are shown as F (significance ratio) and P (significance level) values. Significance of differences was set at $P<0.05$. Prior to analysis, data not matching a normal distribution (Kolmogorov-Smirnov test at the 95\% confidence interval) were log-transformed. The Pearson $r$ moment was used to seek for correlations among different elements. 


\section{Results}

\subsection{Influence of site on lichen diversity}

The diversity of epiphytic lichens, expressed in terms of ILD, increased with distance from vehicle traffic (Tab. 1). Approaching car traffic, overall species richness decreased from 24 to 20 species, non-nitrophilous lichens decreased and nitrophilous ones increased. Figure 1 shows that the presence of traffic enhances nitrophilous and toxitolerant lichens: $83 \%$ of lichen frequencies on roadside trees are determined by nitrophilous species on both sides of the bole. In the urban park this percentage falls to 53\% (exposed side) and 56\% (sheltered side), respectively. In particular, the frequencies of the following nitrophilous lichens significantly increased on road lining trees: Hyperphyscia adglutinata, Lecanora chlarotera and Lecidella elaeochroma and, to a lesser extent, also Candelariella reflexa. On the contrary, the frequencies of the non-nitrophilous lichens Candelariella xanthostigma, Flavoparmelia caperata, Parmelia sulcata, Parmelina tiliacea, Parmotrema perlatum and Punctelia borreri significantly decreased. The fruticose lichens Evernia prunastri, Ramalina farinacea and Ramalina fastigiata, regarded as species sensitive to air pollution, disappeared from tree trunks in proximity of vehicular traffic; however, several small thalli were observed at heights $>2.5 \mathrm{~m}$ also on road lining trees, where they could probably find enough shelter from dust resuspended by vehicles.

\subsection{Influence of angular exposure on lichen diversity}

On the whole, lichen diversity in terms of ILD did not show significant variations according to angular exposure to traffic (Tab. 2). On roadside trees, 17 species were recorded on the street-facing side (NE) and 18 on the opposite side (SW). Although C. reflexa and Physconia grisea tended to decrease and some nitrophilous lichens, namely $L$.

chlarotera and $X$. parietina were more abundant on the traffic-exposed side, none of the recorded species had a marked variation of its frequency according to the angular exposure to traffic $(\mathrm{P}>0.05)$.

In the urban park, 22 species were recorded on the street-facing side and 18 on the opposite side (SW). Frequencies of the non-nitrophilous lichen P. sulcata were markedly higher at the street-facing side of the bole $(\mathrm{P}<0.05)$.

The following non nitrophilous and mesophilous species were recorded only at the NE side in the urban park: Pertusaria albescens (crustose lichen) Physconia perisidiosa, P. servitii (foliose lichens) E. prunastri, R. farinacea and $R$. fastigiata (fruticose lichens). In the drier (SW) side of the bole, the xerophilous crustose Amandinea punctata and the foliose species Physcia biziana were exclusive species, while C. xanthostigma and H. adglutinata were more abundant.

\subsection{Influence of site on metal accumulation}

Metal concentrations were generally low at both sites and according to the interpretative scale suggested by Bargagli and Nimis (2002) are indicative of a moderately polluted environment.

Mean concentrations of $\mathrm{Ba}, \mathrm{Cr}, \mathrm{Cu}, \mathrm{Mn}, \mathrm{Sb}$ and $\mathrm{Zn}$ were significantly higher $(\mathrm{P}<0.05)$ in samples from roadside trees (Tab. 3). Positive reciprocal correlations among the above elements (Tab. 4) pinpoint traffic as a common source for these elements that, as a consequence, can be regarded as TREs. On the other hand, higher levels of Al (soil-related element) and $\mathrm{V}$ were recorded at the urban park.

\subsection{Influence of angular exposure on metal accumulation}


On road lining trees, TREs were similar at both trunk sides, irrespective of angular exposure to traffic, while on trees in the urban park (250 m away) statistically significant differences $(\mathrm{P}<0.05)$ emerged for $\mathrm{Cu}$ and $\mathrm{Sb}(\mathrm{Tab} .5)$. Of the other elements, $\mathrm{Al}$ and $\mathrm{Pb}$ were differentiated by side at both sites, and $\mathrm{Fe}$ was significantly higher at the sheltered site only on road lining trees.

\section{Discussion}

\subsection{Lichen diversity}

Epiphytic lichen diversity depends on the joint effects of interacting variables, which play a main role also in the vicinity of busy roads. These variables include airborne pollutants (Nimis et al. 2002), microclimate (Barkman 1958), dust depositions (Loppi and Pirintsos 2000), habitat eutrophication (Seaward and Coppins 2004; Paoli et al. 2006), artificiality of the environment (Gombert et al. 2004) and bark properties (Van Herk 2002; Loppi and Frati 2004). Different pollutants may have contrasting effects on lichen communities. It is well-known that the lichen diversity is more influenced by gaseous pollutants like $\mathrm{SO}_{2}$ (Seaward 1993) and $\mathrm{NO}_{x}$ (Davies et al. 2007) originating from combustion processes than by heavy metals and particulate matter. In fact, lichens can accumulate trace elements at levels far above their physiological requirements without suffering damaging effects. In many urban areas, $\mathrm{NO}_{\mathrm{x}}$ is now considered the major pollutant in proximity of areas subjected to intense vehicular traffic (Wolseley et al. 2004). Increasing $\mathrm{NO}_{\mathrm{x}}$ level has led to a parallel increase of nitrophilous lichen species in urban environments (Gombert et al. 2004; Davies et al. 2007), whereas in rural environments the effects of agricultural practices still overbear the effects of $\mathrm{NO}_{2}$ and $\mathrm{NH}_{3}$ emitted by road traffic (Frati et al. 2006).

A study carried out in 1995 in the urban area of Siena (Monaci et al. 1997) reported the lowest lichen diversity at stations with the heaviest traffic and indicated car exhaust as the main source of air pollution. A successive lichen survey reported a general trend of ameliorating conditions as the result of an improvement in air quality over time (Loppi et al. 2002). Our data, interpreted in terms of air pollution (Paoli and Loppi 2008), confirm this trend, indicating low pollution at the busy site and negligible pollution at the urban park.

Our results showed that the lichen diversity was not influenced by angular exposure on the tree bole, but increased with distance from vehicular traffic, both in terms of ILD and species richness.

A study on the angular distribution of epiphytic lichens on Tilia trunks in moderately polluted environments showed that nitrophilous species (i.e. Physcia adscendens, Candelaria concolor and X. parietina) and weakly basophilous lichens (such as P. subrudecta) were more abundant on the tree side facing vehicular traffic because of the eutrophication induced by dust and spray lifted by cars (Del Guasta 2000). On the contrary, meso-acidophilous lichens such as $F$. caperata, and P. tiliacea were scarce in proximity of vehicular traffic and did not show preferential distribution on the bole. It is well-known that in the Mediterranean area dust promotes nitrophilous lichens (Loppi and De Dominicis 1996; Loppi and Pirintsos 2000) and that the epiphytic lichen vegetation composed of communities dominated by $F$. caperata and $P$. perlatum, when influenced by sources of dust such as dirt roads, shifts towards communities dominated by $X$. parietina and P. adscendens (Loppi 1996).

Similarly, in the urban area of Siena we observed a shift from meso-acidophilous to xero-nitrophilous lichens approaching busy roads. Furthermore, with increasing distance from direct pollution sources, such as in the urban park, the frequency of mesophilous species increases on the street-facing side of tree trunks and that of xerophilous ones increases on the sheltered side. These evidences confirm that microclimatic conditions are the key factor that most 
influences the composition of lichen vegetation far from direct pollution sources. In lichen monitoring for bioindication purposes, it should be taken into account that approaching the traffic source, non-nitrophilous lichens decrease while nitrophilous ones may increase. Oligotrophic, hygrophytic and acidophilous lichens are sensitive to pollution caused by traffic, and their richness declines markedly close to roads (Llop et al. 2011). These lichen groups are considered functional response groups - species that have a similar response to an environmental factor (Lavorel et al. 2002), and their use as indicators of air quality in urban environments seemed even more reliable than the total diversity for evaluating the impact of atmospheric pollution in small urban areas (Llop et al. 2011). This may have important consequences on the interpretation of ILD values and agrees with the conclusions of Loppi and Nascimbene (2010), that in the presence of nitrogen emissions, the response of nitrophilous species should be considered separately in the calculation of ILD values.

\subsection{Metal accumulation}

It is well known that the chemical composition of lichens reflects the availability of elements in the environment (Garty 1993; Bačkor and Loppi 2009). In particular, several studies showed patterns of element accumulation related with distance from vehicle traffic. Zechmeister et al. (2005) investigated element deposition from road traffic in Austria using mosses and identified, among others, TREs associated to particulate matter ( $\mathrm{Cr}, \mathrm{Sb}, \mathrm{Zn}, \mathrm{Fe}, \mathrm{V}, \mathrm{Cu}, \mathrm{Ni})$ that were mainly deposited within a distance of $250 \mathrm{~m}$ from major roads. Traffic density, distance from and elevation of the road were identified as the most influencing factors for the deposition of such elements. Cuny et al. (2001) found correlations between traffic and the accumulation of $\mathrm{Pb}, \mathrm{Zn}$ and $\mathrm{Cd}$ in $F$. caperata thalli transplanted in the neighborhood of a motorway in France. Loppi et al. (1994; 1995) found heavy metal air pollution ( $\mathrm{Cd}, \mathrm{Cr}, \mathrm{Cu}, \mathrm{Ni}, \mathrm{Pb}$ and $\mathrm{Zn})$ in $F$. caperata in urban areas of central Italy linked to vehicular traffic. However, our results showed that the accumulation of TREs in lichens on roadside trees was not influenced by angular exposure to traffic.

In urban environments, road dust entrained into the air by vehicle flow is a major source of ambient particulate matter $\left(\mathrm{PM}_{10}\right)$ (Abu-Allaban et al. 2003). Oliveira et al. (2010) analyzed the ionic and elemental composition of the fine (PM 2.5$)$ and coarse $\left(\mathrm{PM}_{2.5-10}\right)$ fraction of aerosol, comparing roadsides and urban backgrounds in the city of Oporto (Portugal) and found that direct car emissions and road dust resuspension contributed up to $66 \%$ of the fine aerosol and up to $55 \%$ of the coarse particles mass at both sites, showing typically highest loads at road side. They also demonstrated that as much as $80 \%$ of the dust present in Oporto can result from road traffic resuspension. Patra et al. (2008) found that resuspension accounts for $40 \%$ of the total material removed from a road segment in London and that coarse particles were resuspended faster and with a clear decay profile than the finer ones, with traffic flow and direction of prevailing winds being major factors in the distance-dependent distribution of particulate matter away from roadsides.

Focusing on the angular exposure of roadside Quercus ilex to TREs in Siena, Bargagli (1998) reported that $\mathrm{Hg}, \mathrm{Cd}, \mathrm{Pb}$, $\mathrm{Zn}, \mathrm{Cu}, \mathrm{Cr}, \mathrm{Al}, \mathrm{Fe}, \mathrm{Mn}, \mathrm{Ni}$ were accumulated with similar efficiencies on both the trunk side directly exposed to traffic emissions and the sheltered side. Similar findings were observed analyzing one-year-old leaves from crown periphery of the same trees: locally, some differences involved $\mathrm{Cd}, \mathrm{Cr}$ and $\mathrm{Mn}$, chiefly entrapped by road facing leaves, and $\mathrm{Cu}$, $\mathrm{Hg}$ and $\mathrm{Zn}$, which were higher in leaves from the opposite side.

Our data showed a symmetrical distribution for almost all the elements, except for some TREs and some soil-related elements. In particular, lower levels of $\mathrm{Cu}$ and $\mathrm{Sb}$ were found in lichens from the sheltered side of trees distant from traffic; moreover, $\mathrm{Sb}$ was positively correlated with $\mathrm{Ba}, \mathrm{Cu}, \mathrm{Cr}$ and $\mathrm{Mn}$. Antimony and $\mathrm{Cu}$ concentrations in airborne dust were found to be dependent on traffic density and distance from traffic (Dietl et al. 1997, Fujiwara et al. 2011). 
Reciprocal correlations of $\mathrm{Sb}, \mathrm{Cu}$ and $\mathrm{Ba}$ were found in $\mathrm{PM}_{10}$ and $\mathrm{PM}_{2.5}$ as a result of dust resuspension at the entrance and exit of tunnels in the USA (Lough et al. 2005) and vehicle emission (namely brake lining) was found as main Sb sources in tunnel aerosols in Sweden (Sternbeck et al. 2002).

The asymmetrical distribution of soil related elements (Al, Fe) and $\mathrm{Pb}$ in our study is likely determined by dust resuspension. In general, high concentrations of lithogenic elements (e.g. Al and Fe) measured in lichens and mosses are associated with high levels of deposition of airborne soil dust (Bargagli, 1998). In our study vanadium is suggested to be of soil origin since this element was highly correlated with $\mathrm{Al}(\mathrm{R}=0.82, \mathrm{P}<0.05)$ and negatively with TREs, suggesting that traffic is not a source of $\mathrm{V}$ in the area. In fact, although $\mathrm{V}$, in association with $\mathrm{Ni}$, is a common tracer of oil combustion, this element can also have a crustal origin (Bargagli 1998). On the other side, $\mathrm{Pb}$ concentrations were shown to decrease by $20 \%$ per year in particulate matter in central Italy (Monaci et al. 2000) and in Tuscany air pollution by $\mathrm{Pb}$ have drastically fallen owing to the ban of leaded gasoline (Loppi et al. 2004). The present levels of $\mathrm{Pb}$ recorded in Siena do not correlate with any of the TREs analyzed and indicate the lack of contamination sources. Overall, our data indicated that the TRE content of lichens on the bole of road-lining trees is similar both on the side exposed to traffic emissions and particulate matter resuspension and on the sheltered side. This can be explained considering that pollutants do not have a sharp horizontal gradient during turbulent diffusion of particulate matter at street level due to urban traffic (Patra et al. 2008), and hence, a markedly different distribution of depositions between the two sides of the trunk does not occur. During lichen collection for bioaccumulation purposes, it is generally recommended that lichen material should be taken from all around the tree trunk to prevent any possible influence of cardinal exposure. However, this is not always possible owing to the lack of enough lichen material. Our results suggest that the angular exposure respect to the traffic source does not influence trace element accumulation. These results are important when using lichens for biomonitoring purposes, both for planning future studies and for the reliability of the interpretation of past surveys that do not report information about the angular exposure of the collected lichen material.

\section{Conclusions}

This study investigated the influence of angular exposure and distance from vehicular traffic on the diversity of epiphytic lichens and the bioaccumulation of traffic-related elements in the town of Siena, where vehicular traffic is the main source of air pollution and the air is only moderately polluted.

As far as distance is concerned, our results showed that the diversity of epiphytic lichens increases with distance from traffic emissions, either in terms of ILD and species richness. However, it should be taken into account that approaching the traffic source, non-nitrophilous lichens decreased while nitrophilous ones increased. This may have important consequences in the interpretation of ILD values and is consistent with the conclusions of Loppi and Nascimbene (2010), that in the presence of nitrogen emissions, the response of nitrophilous species should be considered separately in the calculation of ILD values, and hence, with the use of lichen functional groups as indicators of air quality in small urban environments as proposed by Llop et al. (2011).

The concentration of the traffic-related elements $\mathrm{Ba}, \mathrm{Cr}, \mathrm{Cu}, \mathrm{Mn}, \mathrm{Sb}$ and $\mathrm{Zn}$ accumulated in thalli of Punctelia borreri was higher on roadside trees than in trees from urban parks.

As far as angular exposure on the tree trunk is concerned, ILD and species richness were not affected by road exposure and also the bioaccumulation of traffic-related elements was similar in lichens from the side of the bole exposed to traffic emissions and particulate resuspension and from the opposite side. 


\section{Acknowledgments}

This paper is dedicated to the memory of the late Prof. Carlo Gaggi (1955-2011), our colleague and friend.

\section{References}

Asta J, Erhardt W, Ferretti M, Fornasier F, Kirschbaum U, Nimis PL, Purvis OW, Pirintsos S, Scheidegger C, Van Haluwyn C, Wirth V (2002) Mapping lichen diversity as an indicator of environmental quality. In: Nimis PL, Scheidegger C, Wolseley PA (eds) Monitoring with Lichens - Monitoring Lichens. Kluwer Academic Publishers, pp 273-279

Abu-Allaban M, Gillies JA, Gertler AW, Clayton R, Profitt D (2003). Tailpipe, resuspended road dust, and brake-wear emission factors from on-road vehicles. Atmos Environ 37:5283-5293

ARPAT (2010) Rapporto provinciale qualità dell'aria di Siena - Anno 2010, pp 47

Bačkor M, Loppi S (2009) Interactions of lichens with heavy metals - A review. Biol Plantarum 53:214-222

Barkman JJ (1958) Phytosociology and ecology of cryptogamic epiphytes. Assen, Netherlands

Bargagli R (1998) Trace elements in terrestrial plants: an ecophysiological approach to biomonitoring and biorecovery. Springer-Verlag, Berlin

Bargagli R, Nimis PL (2002) Guidelines for the use of epiphytic lichens as biomonitors of atmospheric deposition of trace elements. In: Nimis PL, Scheidegger C, Wolseley PA(eds) Monitoring with Lichens - Monitoring Lichens. Kluwer Academy Publishers, pp 295-299

Bari A, Rosso A, Minciardi MR, Troiani F, Piervittori R (2001) Analysis of heavy metals in atmospheric particulates in relation to their bioaccumulation in explanted Pseudevernia furfuracea thalli. Environ Monit Assess 69:205-220

Bettinelli M, Spezia S, Bizzarri G (1996) Trace element determination in lichens by ICP-MS. Atom Spectrosc 17:133141

Cadle SH, Mulawa PA, Ball J, Donase C, Weibel A, Sagebiel JC, Knapp KT, Snow R (1997) Particulate emission rates from in-use high-emitting vehicles recruited in Orange County, California. Environ Sci Technol 31:3405-3412

Campo G, Orsi M, Badino G, Giacomelli R, Spezzano P (1996) Evaluation of motorway pollution in a mountain ecosystem. Pilot project: Susa Valley (Northwest Italy) years 1990-1994. Sci Total Environ 189/190:161-166

Cape JN, Tang YS, Van Dijk N, Love L, Sutton MA, Palmer SCF (2004) Concentrations of ammonia and nitrogen dioxide at roadside verges, and their contribution to nitrogen deposition. Environ Pollut 132:469-478

Cislaghi C, Nimis PL 1997. Lichens, air pollution and lung cancer. Nature 387:463-464

Cuny D, Van Haluwyn C, Pesch R (2001) Biomonitoring of trace elements in air and soil compartments along the major motorway in France. Water Air Soil Pollut 125:273-289

Davies L, Bates JW, Bell JNB, James PW, Purvis OW (2007) Diversity and sensitivity of epiphytes to oxides of nitrogen in London. Environ Pollut 146:299-310

Del Guasta M (2000) Angular distribution of epiphytic lichens on Tilia trees as a result of car traffic. Allionia 37:233240

Dietl C, Reifenhaüser W, Peichl L (1997) Association of antimony with traffic-occurrence in airborne dust, deposition and accumulation in standardized grass cultures. Sci Total Environ 205:235-244

Ferry BW, Baddeley MS, Hawksworth DL (1973) Air pollution and lichens - The Althone Press, London

Frati L, Caprasecca E, Santoni S, Gaggi C, Guttová A, Gaudino S, Pati A, Rosamilia S, Pirintsos SA, Loppi S (2006) Effects of $\mathrm{NO}_{2}$ and $\mathrm{NH}_{3}$ from road traffic on epiphytic lichens. Environ Pollut 142:58-64

Fujiwara F, Rebagliati RJ, Marrero J, Gómez D, Smichowski P (2011) Antimony as a traffic-related element in size- 
fractionated road dust samples collected in Buenos Aires. Microchem J 97:62-67

Garty J (1993) Lichens as biomonitors for heavy metal pollution. In: Markert B (ed) Plants as Biomonitors. VCH, Weinheim, pp 193-263

Garty J (2001) Biomonitoring atmospheric heavy metals with lichens: Theory and application. Crit Rev Plant Sci 20:309-371

Gombert S, Asta J, Seaward MRD (2004) Assessment of lichen diversity by index of atmospheric purity (IAP), index of human impact (IHI) and other environmental factors in an urban area (Grenoble, southeast France). Sci Total Environ 324:183-199

Helmers E (1996) Elements accompanying platinum emitted from automobile catalysts. Chemosphere 33:405-419

Helmers E (2000) PGE emissions of automobile catalysts-identifying their track in the environment. A challenge to analytical strategy and assessment. In: Zereini F, Alt F (eds) Anthropogenic platinum group element emissions. Their impact on man and environment. Springer 133-144.

Hopke PK, Lamb RE, Natusch DFS (1980) Multielemental characterization of urban roadway dust. Environ Sci Technol 14:164-172

Lavorel S, Garnier E, Lavorel S (2002) Predicting changes in community composition and ecosystem functioning from plant traits: revisiting the Holy Grail. Funct Ecol 16:545-556

Llop E, Pinho P, Matos P, Pereira MJ, Branquinho C (2011) The use of lichen functional groups as indicators of air quality in a Mediterranean urban environment. Ecol Indic 13:215-221

Loppi S (1996) Effects of road dust contamination on epiphytic lichen communities (central Italy). Micologia e Vegetazione Mediterranea 11:155-160

Loppi S, De Dominicis V (1996) Effects of agriculture on epiphytic lichen vegetation in central Italy. Israel J Plant Sci 44:297-307.

Loppi S, Frati L (2004) Influence of tree substrate on the diversity of the epiphytic lichens: Comparison between Tilia platyphyllos and Quercus ilex (Central Italy). Bryologist 107:340-344

Loppi S, Nascimbene J (2010) Monitoring $\mathrm{H}_{2} \mathrm{~S}$ air pollution caused by the industrial exploitation of gethoermal energy: the pitfall of using lichens as bioindicators. Environ Pollut 158:2635-2639.

Loppi S, Pirintsos SA (2000) Effect of dust on epiphytic lichen vegetation in the Mediterranean area (Italy and Greece). Israel J Plant Sci 48:91-95

Loppi S, Chiti F, Corsini A, Bernaldi L (1994) Lichen biomonitoring of trace metals in the Pistoia area (central-northern Italy). Environ Monit Assess 24:17-27

Loppi S, Corsini A, Bruscoli C, Rossetti C (1995) Lichen biomonitoring of heavy metals in Montecatini Terme (centralnorthern Italy). Micologia e Vegetazione Mediterranea 10:122-128

Loppi S, Frati L, Paoli L, Bigagli V, Rossetti C, Bruscoli C, Corsini A (2004) Biodiversity of epiphytic lichens and heavy metal contents of Flavoparmelia caperata thalli as indicators of temporal variations of air pollution in the town of Montecatini Terme (central Italy). Sci Total Environ 326:113-122

Loppi S, Ivanov D, Boccardi R (2002) Biodiversity of epiphytic lichens and air pollution in the town of Siena (Central Italy). Environ Pollut 116:123-128

Lough G, Schauer JJ, Soopark J, Shafer M, Deminter J, Weinstein JP (2005) Emissions of metals associated with motor vehicle roadways. Environ Sci Technol 39:826-836

Lowenthal DH, Zielinska B, Chow JC, Watson JCW, Gautam M, Ferguson DH, Neuroth GR, Stevens KD (1994) 
Characterisation of heavy duty vehicle emissions. Atmos Environ 28:731-743

Monaci F, Bargagli R, Gasparo D (1997) Air pollution monitoring by lichens in a small medieval town of central Italy. Acta Bot Neerl 46:403-412

Monaci F, Moni F, Lanciotti E, Grechi D, Bargagli R (2000) Biomonitoring of aiborne metals in urban environments: new tracers of vehicle emission, in place of lead. Environ Pollut 107:321-327

Morcelli CPR, Figueiredo AMG, Sarkis JES, Enzweiler J, Kakazu M, Sigolo JB (2005) PGEs and other traffic-related elements in roadside soils from São Paulo, Brazil. Sci Total Environ 345:81-91

Oliveira C, Pio C, Caseiro A, Santos P, Nunes T, Mao H, Luahana L, Sokhi R (2010) Road traffic impact on urban atmospheric aerosol loading at Oporto, Portugal. Atmos Environ 44:3147-3158

Nimis PL, Martellos S (2008) ITALIC - The Information System on Italian Lichens. Version 4.0. University of Trieste, Dept. of Biology, IN4.0/1 (http://dbiodbs.univ.trieste.it/)

Nimis PL, Scheidegger C, Wolseley PA (2002) Monitoring with Lichens - Monitoring Lichens. NATO Science Series Kluwer Academic Publishers, pp 408

Paoli L, Loppi S (2008) A biological method to monitor early effect of the air pollution caused by the industrial exploitation of geothermal energy. Environ Pollut 155:383-388.

Paoli L, Guttová A, Loppi S (2006) Assessment of environmental quality by the diversity of epiphytic lichens in a semiarid mediterranean area (Val Basento, South Italy). Biologia 61:353-359

Patra A, Colvile R, Arnold S, Bowen E, Shallcross D, Martin D, Price C, Tate J, ApSimon H, Robins A (2008) On street observations of particulate matter movement and dispersion due to traffic on an urban road. Atmos Environ 42:3911-3926

Que Hee SS (1994) Availability of elements in leaded/unleaded automobile exhaust, a leaded paint, a soil and some mixtures. Arch Environ Con Tox 27:145-153

Seaward MRD (1993) Lichens and sulphur dioxide air pollution: field studies. Environ Rev 1:73-91.

Seaward MRD, Coppins BJ (2004) Lichens and hypertrophication. Bibl Lichenol 88:561-572

Sloof JE (1995) Lichens as quantitative biomonitors for atmospheric trace-element deposition, using transplants. Atmos Environ 29:11-20

Sternbeck J, Sjödin A, Andréasson K (2002) Metal emissions from road traffic and the influence of resuspension results from two tunnel studies. Atmos Environ 36:4735-4744

Sutton MA, Dragosits U, Tang YS, Fowler D (2000) Ammonia emissions from non-agricultural sources in the UK. Atmos Environ 34:855-869

Van Herk CM (2002) Epiphytes on wayside trees as an indicator of eutrophication. In: Nimis PL, Scheidegger C, Wolseley PA (eds) Monitoring with Lichens - Monitoring Lichens. Kluwer Academic Publishers, pp 285-289

Van Herk K, Aptroot A (2000) The sorediate Punctelia species with lecanoric acid in Europe. Lichenologist 32:233-246

Von Uexküll O, Skerfving S, Doyle R, Braungart M (2005) Antimony in brake pads - a carcinogenic component? J Clean Prod 13:19-31

Wolseley PA, James PW, Purvis OW, Leith ID, Sutton MA (2004) Bioindicator methods for nitrogen based on community species composition: Lichens. In: Sutton MA, Pitcairn CER, Whitfield CP (eds) Bioindicator and biomonitoring methods for assessing the effects of atmospheric nitrogen on statutory nature conservation sites. JNCC Report No. 356 pp 75-85

Zechmeister HG, Hohenwallner D, Riss A, Hanus-Illnar A (2005) Estimation of element deposition derived from road 
traffic sources by using mosses. Environ Pollut 138:238-249 
Table 1. Index of Lichen Diversity and average frequency of epiphytic lichens found during the study. Values in bold differ significantly $(\mathrm{P}<0.05)$ by site. Results of ANOVA are shown as $\mathrm{F}$ - and $\mathrm{P}$ - values.

\begin{tabular}{|c|c|c|c|c|c|}
\hline Index of Lichen Diversity \pm SD & $\begin{array}{c}\begin{array}{c}\text { Road lining } \\
\text { trees }\end{array} \\
\mathbf{1 0 8} \pm \mathbf{1 7}\end{array}$ & $\begin{array}{l}\text { Urban park } \\
250 \text { m away } \\
\mathbf{1 3 7} \pm \mathbf{2 5}\end{array}$ & $\begin{array}{r}F=7.420 \\
P=0.015\end{array}$ & $\begin{array}{l}\mathrm{F}=0.000 \\
\mathrm{P}=1.000\end{array}$ & $\begin{array}{c}\text { Site* } \\
\text { Angular } \\
\text { Exposure } \\
\mathrm{F}=0.693 \\
\mathrm{P}=0.417\end{array}$ \\
\hline Candelaria concolor $^{a}$ & 8.2 & 9.2 & $\begin{array}{l}\mathrm{F}=0.057 \\
\mathrm{P}=0.814\end{array}$ & $\begin{array}{l}F=0.138 \\
P=0.715\end{array}$ & $\begin{array}{l}F=0.344 \\
P=0.565\end{array}$ \\
\hline Candelariella reflexa ${ }^{a}$ & 4.6 & 2.4 & $\begin{array}{l}F=0.464 \\
P=0.505\end{array}$ & $\begin{array}{l}F=1.898 \\
P=0.187\end{array}$ & $\begin{array}{l}F=3.163 \\
P=0.094\end{array}$ \\
\hline Candelariella xanthostigma & 4.2 & 12.6 & $\begin{array}{l}F=5.226 \\
P=0.036\end{array}$ & $\begin{array}{l}F=1.037 \\
P=0.324\end{array}$ & $\begin{array}{l}\mathrm{F}=4.207 \\
\mathrm{P}=0.057\end{array}$ \\
\hline Flavoparmelia caperata & 1.4 & 7.6 & $\begin{array}{l}F=7.359 \\
P=0.015\end{array}$ & $\begin{array}{l}F=0.022 \\
P=0.885\end{array}$ & $\begin{array}{l}F=0.903 \\
P=0.356\end{array}$ \\
\hline Hyperphyscia adglutinata ${ }^{a}$ & 20 & 14.4 & $\begin{array}{l}F=4.942 \\
P=0.041\end{array}$ & $\begin{array}{l}F=0.000 \\
P=0.992\end{array}$ & $\begin{array}{l}F=0.000 \\
P=0.992\end{array}$ \\
\hline Lecanora chlarotera ${ }^{a}$ & 5.6 & 0.4 & $\begin{array}{l}F=37.22 \\
P=0.000\end{array}$ & $\begin{array}{c}F=1.81 \\
P=0.197\end{array}$ & $\begin{array}{c}F=1.81 \\
P=0.197\end{array}$ \\
\hline Lepraria sp. & 1.6 & 2.8 & $\begin{array}{l}\mathrm{F}=0.127 \\
\mathrm{P}=0.726\end{array}$ & $\begin{array}{l}F=1.761 \\
P=0.203\end{array}$ & $\begin{array}{l}\mathrm{F}=0.127 \\
\mathrm{P}=0.726\end{array}$ \\
\hline Parmelia sulcata & 1 & 8.4 & $\begin{array}{l}F=16.46 \\
P=0.001\end{array}$ & $\begin{array}{c}F=7.88 \\
P=0.013\end{array}$ & $\begin{array}{c}\mathrm{F}=2.01 \\
\mathrm{P}=0.176\end{array}$ \\
\hline Parmelina tiliacea & 1.8 & 9.2 & $\begin{array}{l}F=13.28 \\
P=0.002\end{array}$ & $\begin{array}{c}F=3.35 \\
P=0.086\end{array}$ & $\begin{array}{l}F=0.002 \\
P=0.988\end{array}$ \\
\hline Phaeophyscia orbicularis ${ }^{a}$ & 4 & 4.4 & $\begin{array}{l}F=0.007 \\
P=0.933\end{array}$ & $\begin{array}{l}F=0.014 \\
P=0.908\end{array}$ & $\begin{array}{l}F=0.188 \\
P=0.670\end{array}$ \\
\hline Physcia adscendens ${ }^{a}$ & 18.6 & 18.4 & $\begin{array}{l}F=0.031 \\
P=0.863\end{array}$ & $\begin{array}{l}F=0.031 \\
P=0.863\end{array}$ & $\begin{array}{l}F=3.367 \\
P=0.085\end{array}$ \\
\hline Physconia grisea ${ }^{a}$ & 16 & 19.4 & $\begin{array}{l}F=4.709 \\
P=0.052\end{array}$ & $\begin{array}{l}F=4.307 \\
P=0.054\end{array}$ & $\begin{array}{l}\mathrm{F}=3.258 \\
\mathrm{P}=0.090\end{array}$ \\
\hline Punctelia borreri & 7.4 & 13.8 & $\begin{array}{l}F=6.093 \\
P=0.025\end{array}$ & $\begin{array}{l}F=0.168 \\
P=0.687\end{array}$ & $\begin{array}{l}F=0.595 \\
P=0.642\end{array}$ \\
\hline Xanthoria parietina $^{a}$ & 6.4 & 6 & $\begin{array}{l}F=0.003 \\
P=0.957\end{array}$ & $\begin{array}{l}F=1.364 \\
P=0.260\end{array}$ & $\begin{array}{l}F=1.428 \\
P=0.249\end{array}$ \\
\hline Melanelixia subaurifera & 0.2 & 1.4 & $\begin{array}{l}F=1.400 \\
P=0.254\end{array}$ & $\begin{array}{l}F=0.019 \\
P=0.893\end{array}$ & $\begin{array}{l}F=0.274 \\
P=0.608\end{array}$ \\
\hline Parmotrema perlatum & & 0.8 & $\begin{array}{l}F=3.455 \\
P=0.082\end{array}$ & $\begin{array}{l}F=0.675 \\
P=0.423\end{array}$ & $\begin{array}{l}F=0.675 \\
P=0.423\end{array}$ \\
\hline Amandinea punctata & & 2 & $\begin{array}{l}F=1.000 \\
P=0.332\end{array}$ & $\begin{array}{l}F=1.000 \\
P=0.332\end{array}$ & $\begin{array}{l}\mathrm{F}=1.000 \\
\mathrm{P}=0.332\end{array}$ \\
\hline Physcia biziana ${ }^{a}$ & & 0.6 & $\begin{array}{l}F=2.457 \\
P=0.137\end{array}$ & $\begin{array}{l}F=2.457 \\
P=0.137\end{array}$ & $\begin{array}{l}F=2.457 \\
P=0.137\end{array}$ \\
\hline Evernia prunastri & & 1.2 & $\begin{array}{l}F=1.000 \\
P=0.332\end{array}$ & $\begin{array}{l}F=1.000 \\
P=0.332\end{array}$ & $\begin{array}{l}F=1.000 \\
P=0.332\end{array}$ \\
\hline Pertusaria albescens & & 0.8 & $\begin{array}{l}F=2.250 \\
P=0.153\end{array}$ & $\begin{array}{l}F=2.250 \\
P=0.153\end{array}$ & $\begin{array}{l}\mathrm{F}=2.250 \\
\mathrm{P}=0.153\end{array}$ \\
\hline Physconia perisidiosa & & 0.2 & $\begin{array}{l}F=1.000 \\
P=0.332\end{array}$ & $\begin{array}{l}F=1.000 \\
P=0.332\end{array}$ & $\begin{array}{l}\mathrm{F}=1.000 \\
\mathrm{P}=0.332\end{array}$ \\
\hline Ramalina fastigiata & & 0.4 & $\begin{array}{l}F=1.000 \\
P=0.332\end{array}$ & $\begin{array}{l}F=1.000 \\
P=0.332\end{array}$ & $\begin{array}{l}F=1.000 \\
P=0.332\end{array}$ \\
\hline Ramalina fraxinea & & 0.2 & $\begin{array}{l}F=1.000 \\
P=0.332\end{array}$ & $\begin{array}{l}F=1.000 \\
P=0.332\end{array}$ & $\begin{array}{l}F=1.000 \\
P=0.332\end{array}$ \\
\hline Physconia servitii & 0.2 & 0.2 & $\begin{array}{l}F=0.000 \\
P=1.000\end{array}$ & $\begin{array}{l}F=0.000 \\
P=1.000\end{array}$ & $\begin{array}{l}F=2.000 \\
P=0.176\end{array}$ \\
\hline Lecidella elaeochroma ${ }^{a}$ & 5.8 & & $\begin{array}{l}F=7.961 \\
P=0.012\end{array}$ & $\begin{array}{l}F=0.128 \\
P=0.725\end{array}$ & $\begin{array}{l}F=0.128 \\
P=0.725\end{array}$ \\
\hline Caloplaca cerinella ${ }^{a}$ & 0.4 & & $\mathrm{~F}=1.000$ & $\mathrm{~F}=1.000$ & $\mathrm{~F}=1.000$ \\
\hline
\end{tabular}




\begin{tabular}{lccccc}
\hline & $\begin{array}{c}\text { Road lining } \\
\text { trees }\end{array}$ & $\begin{array}{c}\text { Urban park } \\
250 \mathrm{~m} \text { away }\end{array}$ & Site & $\begin{array}{c}\text { Angular } \\
\text { Exposure }\end{array}$ & $\begin{array}{c}\text { Site* } \\
\text { Angular } \\
\text { Exposure }\end{array}$ \\
& & & $\mathrm{P}=0.332$ & $\mathrm{P}=0.332$ & $\mathrm{P}=0.332$ \\
& & & $\mathrm{~F}=1.000$ & $\mathrm{~F}=1.000$ & $\mathrm{~F}=1.000$ \\
Phaeophyscia hirsuta $^{a}$ & \multirow{2}{*}{0.4} & $\mathrm{P}=0.332$ & $\mathrm{P}=0.332$ & $\mathrm{P}=0.332$ \\
& & $\mathrm{~F}=1.000$ & $\mathrm{~F}=1.000$ & $\mathrm{~F}=1.000$ \\
Lecanora carpinea & \multirow{2}{*}{0.2} & $\mathrm{P}=0.332$ & $\mathrm{P}=0.332 \quad \mathrm{P}=0.332$ \\
\hline
\end{tabular}

${ }^{a}$ nitrophilous species (Nimis and Martellos, 2008) 
Table 2. Influence of the angular exposure to traffic (exposed and sheltered sides of the bole) on Index of Lichen Diversity and average frequency of recorded epiphytic lichens. Within each site, values in bold differ significantly $(\mathrm{P}<0.05)$ by bole side.

Street side $\quad$ Sheltered side

Index of Lichen Diversity \pm SD

Candelaria concolor $^{a}$

Candelariella reflexa ${ }^{a}$

Candelariella xanthostigma

Flavoparmelia caperata

Hyperphyscia adglutinata ${ }^{a}$

Lecanora chlarotera ${ }^{a}$

Lepraria sp.

Parmelia sulcata

Parmelina tiliacea

Phaeophyscia orbicularis ${ }^{a}$

Physcia adscendens ${ }^{a}$

Physconia grisea ${ }^{a}$

Punctelia borreri

Xanthoria parietina ${ }^{a}$

Melanelixia subaurifera

Parmotrema perlatum

Amandinea punctata

Physcia biziana ${ }^{a}$

Evernia prunastri

Pertusaria albescens

Physconia perisidiosa

Ramalina fastigiata

Ramalina fraxinea

Physconia servitii

Lecidella elaeochroma ${ }^{a}$

Caloplaca cerinella ${ }^{a}$

Phaeophyscia hirsuta ${ }^{a}$

Lecanora carpinea

${ }^{a}$ nitrophilous species (Nimis and Martellos, 2008)

0.4

0.2
Road lining trees

$52 \pm 8$

Urban park - 250 m away

$$
\text { Street side Sheltered side }
$$

\begin{tabular}{|c|c|c|c|}
\hline 3.4 & 4.8 & 6 & 3.2 \\
\hline 0.4 & 4.2 & 1.4 & 1 \\
\hline 2.2 & 2 & 4.2 & 8.4 \\
\hline 0.4 & 1 & 4.6 & 3 \\
\hline 10 & 10 & 6.4 & 8 \\
\hline 3.6 & 2 & 0.2 & 0.2 \\
\hline 1.2 & 0.4 & 2.4 & 0.4 \\
\hline 0.8 & 0.2 & 6.4 & 2 \\
\hline 0.4 & 1.4 & 3.4 & 5.8 \\
\hline 1.8 & 2.2 & 2.4 & 2 \\
\hline 9.8 & 8.8 & 8.6 & 9.8 \\
\hline 6.8 & 9.2 & 9.6 & 9.8 \\
\hline 3.2 & 4.2 & 8 & 5.8 \\
\hline 4.4 & 2 & 3 & 3 \\
\hline \multirow[t]{4}{*}{0.2} & & 0.4 & 1 \\
\hline & & 0.6 & 0.2 \\
\hline & & & 2 \\
\hline & & & 0.6 \\
\hline
\end{tabular}

1.2

0.8

0.2

0.4

0.2

0.2

0.2 
Table 3. Element concentrations (ppm dw) in lichen samples growing on road lining trees and in the urban park. Values in bold differ significantly $(\mathrm{P}<0.05)$ by site. Results of ANOVA are shown as $\mathrm{F}$ - and $\mathrm{P}$ - values.

\begin{tabular}{|c|c|c|c|c|c|}
\hline & Road lining trees & $\begin{array}{c}\text { Urban park - } 250 \\
\text { m away }\end{array}$ & Site & Angular Exposure & $\begin{array}{l}\text { Site *Angular } \\
\text { Exposure }\end{array}$ \\
\hline $\mathrm{Ba}$ & $5.3 \pm 0.5$ & $4.4 \pm 0.4$ & $\begin{array}{l}F=27.04 \\
P=0.001\end{array}$ & $\begin{array}{l}\mathrm{F}=0.510 \\
\mathrm{P}=0.095\end{array}$ & $\begin{array}{l}F=14.25 \\
P=0.005\end{array}$ \\
\hline $\mathrm{Cr}$ & $1.4 \pm 0.2$ & $1.1 \pm 0.2$ & $\begin{array}{l}F=7.254 \\
P=0.027\end{array}$ & $\begin{array}{l}F=1.434 \\
P=0.265\end{array}$ & $\begin{array}{l}F=1.877 \\
P=0.208\end{array}$ \\
\hline $\mathrm{Cu}$ & $7.6 \pm 0.4$ & $6.0 \pm 1.0$ & $\begin{array}{l}F=\mathbf{5 5 . 3 6} \\
P=\mathbf{0 . 0 0 0}\end{array}$ & $\begin{array}{l}F=15.81 \\
P=0.004\end{array}$ & $\begin{array}{l}F=17.28 \\
P=0.003\end{array}$ \\
\hline $\mathrm{Mn}$ & $12.3 \pm 0.2$ & $9.8 \pm 0.3$ & $\begin{array}{l}F=222.7 \\
P=0.000\end{array}$ & $\begin{array}{l}F=0.001 \\
P=0.985\end{array}$ & $\begin{array}{l}F=0.500 \\
P=0.509\end{array}$ \\
\hline $\mathrm{Sb}$ & $0.52 \pm 0.07$ & $0.26 \pm 0.11$ & $\begin{array}{l}F=103.1 \\
P=0.000\end{array}$ & $\begin{array}{l}F=7.400 \\
P=0.026\end{array}$ & $\begin{array}{l}\mathbf{F}=\mathbf{3 1 . 8 0} \\
\mathbf{P}=\mathbf{0 . 0 0 0}\end{array}$ \\
\hline $\mathrm{Zn}$ & $41.5 \pm 5.1$ & $35.6 \pm 6.0$ & $\begin{array}{l}F=12.20 \\
P=0.010\end{array}$ & $\begin{array}{l}F=1.820 \\
P=0.219\end{array}$ & $\begin{array}{l}F=0.130 \\
P=0.726\end{array}$ \\
\hline $\mathrm{Al}$ & $211 \pm 18$ & $275 \pm 41$ & $\begin{array}{l}F=23.81 \\
P=0.001\end{array}$ & $\begin{array}{l}F=0.020 \\
P=0.881\end{array}$ & $\begin{array}{l}\mathbf{F}=\mathbf{1 3 . 1 4} \\
\mathbf{P}=\mathbf{0 . 0 0 7}\end{array}$ \\
\hline $\mathrm{V}$ & $1.06 \pm 0.13$ & $1.58 \pm 0.11$ & $\begin{array}{l}F=74.96 \\
P=0.000\end{array}$ & $\begin{array}{l}F=2.790 \\
P=0.134\end{array}$ & $\begin{array}{l}F=2.510 \\
P=0.152\end{array}$ \\
\hline $\mathrm{Cd}$ & $0.20 \pm 0.01$ & $0.19 \pm 0.01$ & $\begin{array}{l}F=1.385 \\
P=0.273\end{array}$ & $\begin{array}{l}F=3.668 \\
P=0.092\end{array}$ & $\begin{array}{l}F=0.238 \\
P=0.639\end{array}$ \\
\hline $\mathrm{Ce}$ & $0.56 \pm 0.142$ & $0.79 \pm 0.26$ & $\begin{array}{l}F=4.481 \\
P=0.067\end{array}$ & $\begin{array}{l}F=2.592 \\
P=0.146\end{array}$ & $\begin{array}{l}F=0.652 \\
P=0.453\end{array}$ \\
\hline $\mathrm{Fe}$ & $228 \pm 37$ & $236 \pm 27$ & $\begin{array}{l}F=0.620 \\
P=0.455\end{array}$ & $\begin{array}{l}F=1.950 \\
P=0.200\end{array}$ & $\begin{array}{l}F=11.08 \\
P=0.010\end{array}$ \\
\hline $\mathrm{Ni}$ & $2.2 \pm 0.7$ & $2.1 \pm 1.0$ & $\begin{array}{l}F=0.085 \\
P=0.778\end{array}$ & $\begin{array}{l}F=0.314 \\
P=0.590\end{array}$ & $\begin{array}{l}F=0.080 \\
P=0.784\end{array}$ \\
\hline $\mathrm{Pb}$ & $5.8 \pm 0.8$ & $6.0 \pm 0.6$ & $\begin{array}{l}F=0.882 \\
P=0.375\end{array}$ & $\begin{array}{l}F=9.661 \\
P=0.014\end{array}$ & $\begin{array}{l}F=0.191 \\
P=0.673\end{array}$ \\
\hline
\end{tabular}


Table 4. Pearson correlation coefficients among trace elements in lichen samples. Only significant $(\mathrm{P}<0.05)$ values are given (n.s. not significant).

\begin{tabular}{|c|c|c|c|c|c|c|c|c|c|c|c|c|c|}
\hline & $\mathrm{Al}$ & $\mathrm{V}$ & $\mathrm{Cr}$ & $\mathrm{Mn}$ & $\mathrm{Fe}$ & $\mathrm{Ni}$ & $\mathrm{Cu}$ & $\mathrm{Zn}$ & $\mathrm{Cd}$ & $\mathrm{Sb}$ & $\mathrm{Ba}$ & $\mathrm{Ce}$ & $\mathrm{Pb}$ \\
\hline $\mathrm{Al}$ & - & & & & & & & & & & & & \\
\hline $\mathrm{V}$ & 0.82 & - & & & & & & & & & & & \\
\hline $\mathrm{Cr}$ & n.s. & n.s. & - & & & & & & & & & & \\
\hline $\mathrm{Mn}$ & -0.61 & -0.87 & 0.66 & - & & & & & & & & & \\
\hline $\mathrm{Fe}$ & 0.68 & n.s. & n.s. & n.s. & - & & & & & & & & \\
\hline $\mathrm{Ni}$ & n.s. & n.s. & n.s. & n.s. & n.s. & - & & & & & & & \\
\hline $\mathrm{Cu}$ & n.s. & -0.63 & 0.81 & 0.80 & n.s. & n.s. & - & & & & & & \\
\hline $\mathrm{Zn}$ & n.s. & n.s. & n.s. & n.s. & n.s. & 0.65 & 0.59 & - & & & & & \\
\hline $\mathrm{Cd}$ & n.s. & n.s. & 0.63 & n.s. & n.s. & n.s. & n.s. & n.s. & - & & & & \\
\hline $\mathrm{Sb}$ & n.s. & -0.68 & 0.74 & 0.78 & n.s. & n.s. & 0.91 & n.s. & n.s. & - & & & \\
\hline $\mathrm{Ba}$ & n.s. & -0.66 & 0.68 & 0.85 & n.s. & n.s. & 0.84 & n.s. & n.s. & 0.93 & - & & \\
\hline $\mathrm{Ce}$ & n.s. & n.s. & n.s. & n.s. & n.s. & n.s. & n.s. & n.s. & n.s. & n.s. & n.s. & - & \\
\hline $\mathrm{Pb}$ & n.s. & n.s. & n.s. & n.s. & n.s. & n.s. & n.s. & n.s. & n.s. & n.s. & n.s. & n.s. & - \\
\hline
\end{tabular}

Table 5. Element concentrations (ppm dw) in lichen thalli growing on road lining trees and in the urban park as a function of angular exposure to vehicular traffic. Within each site, values in bold differ significantly $(\mathrm{P}<0.05)$ by bole side.

\begin{tabular}{|c|c|c|c|c|}
\hline & \multicolumn{2}{|c|}{ Road lining trees } & \multicolumn{2}{|c|}{ Urban park - $250 \mathrm{~m}$ away } \\
\hline & Street side & Sheltered side & Street side & Sheltered side \\
\hline $\mathrm{Ba}$ & $5.04 \pm 0.29$ & $5.47 \pm 0.55$ & $4.66 \pm 0.41$ & $4.21 \pm 0.22$ \\
\hline $\mathrm{Cr}$ & $1.35 \pm 0.18$ & $1.37 \pm 0.20$ & $1.23 \pm 0.14$ & $1.01 \pm 0.11$ \\
\hline $\mathrm{Cu}$ & $7.60 \pm 0.30$ & $7.65 \pm 0.52$ & $6.81 \pm 0.52$ & $5.19 \pm 0.22$ \\
\hline $\mathrm{Mn}$ & $12.33 \pm 0.04$ & $12.20 \pm 0.35$ & $9.72 \pm 0.37$ & $9.81 \pm 0.22$ \\
\hline $\mathrm{Sb}$ & $0.477 \pm 0.034$ & $0.565 \pm 0.078$ & $0.355 \pm 0.051$ & $0.163 \pm 0.004$ \\
\hline $\mathrm{Zn}$ & $43.9 \pm 6.2$ & $39.1 \pm 3.2$ & $34.1 \pm 2.6$ & $37.0 \pm 8.8$ \\
\hline $\mathrm{Al}$ & $192 \pm 5$ & $231 \pm 26$ & $304 \pm 43$ & $246 \pm 13$ \\
\hline $\mathrm{V}$ & $0.98 \pm 0.06$ & $1.15 \pm 0.12$ & $1.58 \pm 0.16$ & $1.58 \pm 0.04$ \\
\hline $\mathrm{Cd}$ & $0.202 \pm 0.016$ & $0.192 \pm 0.004$ & $0.197 \pm 0.013$ & $0.181 \pm 0.010$ \\
\hline $\mathrm{Ce}$ & $0.663 \pm 0.203$ & $0.495 \pm 0.054$ & $0.682 \pm 0.253$ & $0.772 \pm 0.237$ \\
\hline $\mathrm{Fe}$ & $199 \pm 7$ & $257 \pm 31$ & $249 \pm 35$ & $223 \pm 10$ \\
\hline $\mathrm{Ni}$ & $2.43 \pm 0.99$ & $1.93 \pm 0.11$ & $2.20 \pm 1.13$ & $2.04 \pm 0.95$ \\
\hline $\mathrm{Pb}$ & $5.2 \pm 0.4$ & $6.3 \pm 0.7$ & $5.6 \pm 0.6$ & $6.4 \pm 0.2$ \\
\hline
\end{tabular}


Figure 1. Total ILD and ILD by nitrophilous lichens on road lining trees and in the urban park - $250 \mathrm{~m}$ away.

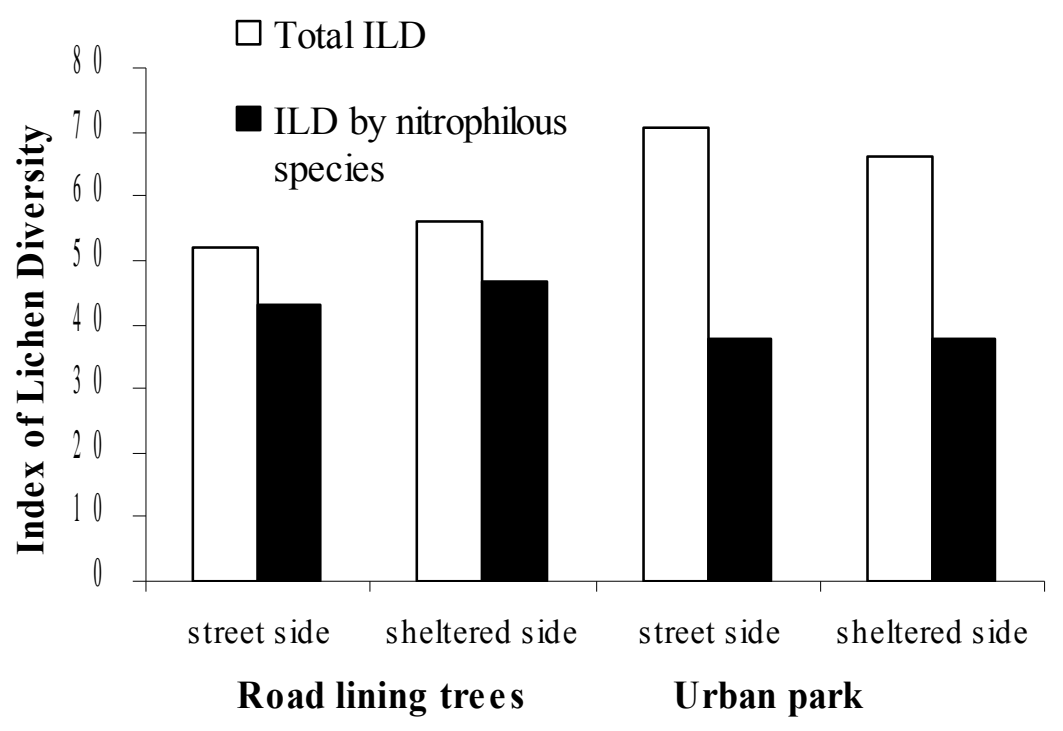

